\title{
"Thou liv'st to all that Read": Reading the Paratext of William Cartwright's Comedies, Tragi-Comedies, With other Poems (1651) as Early Modern Life Writing
}

\author{
Sarah Herbe
}

University of Salzburg, Austria

\section{ABSTRACT IN ENGLISH}

This essay proposes to read the paratext of books published in seventeenth-century England as a form of multi-perspective, multi-generic, and multi-modal life writing, since information on the author is not only provided in chronological "Life of the Author" narratives, but by all elements of the paratext. Drawing on the paratext of William Cartwright's Comedies, Tragi-Comedies, With other Poems, published posthumously in 1651, it is shown how conventional paratextual strategies are combined with individualising "biographemes" ( $R$. Barthes) to create a multi-faceted presentation of the author, in which the reader's role to reconstruct the author's life emerges as central.

\section{ABSTRACT IN GERMAN}

Dieser Aufsatz liest die Paratexte von im siebzehnten Jahrhundert in England gedruckten Büchern als multi-perspektivische, multi-generische und multimodale Form des Life Writing, da Information über das Leben und Werk der AutorInnen nicht nur in ausdrücklich gekennzeichneten biographischen Einleitungen zu finden sind. Basierend auf einer Analyse des Paratextes von William Cartwrights Comedies, Tragi-Comedies, With other Poems, erschienen im Jahr 1651, wird gezeigt, wie konventionelle paratextuelle Strategien mit individualisierenden „Biographemen“ (R. Barthes) zu einer facettenreichen Darstellung des Autors beitragen. Die Rolle, die die Leser in der Rekonstruktion des Lebens des Autors einnehmen, erscheint dabei als zentral. 
Keywords: paratext; biographemes; seventeenth century; England; William Cartwright

\section{INTRODUCTION}

Seven years after the author's death, William Cartwright's Comedies, TragiComedies, With other Poems were published by Humphrey Moseley in 1651. More than a sixth of this volume is taken up by what Gérard Genette has termed the paratext ${ }^{1}$ of books and what is alternatively known as front matter: "anything other than the text proper, including the title page, preface, frontispiece, dedicatory epistles and poems, tables, indices, errata, and colophons" (Voss 1998, 735). However, despite the growing popularity of biography in England in the seventeenth century, no "Life of the Author" is included among the more than 120 pages introducing Cartwright's plays and poems. This does not present an exceptional case in mid-seventeenth century England. Though the first English-language biography had been prefixed to the work of an English writer in Thomas Speght's edition of Chaucer's Works in 1598 (Machan 1995, 154), the "Life of the Author" did not become a regular feature of the paratext of collections of poetry or plays until the beginning of the eighteenth century. Prefatory lives were added to the works of clergymen and classical authors, but not, generally, to the works of poets or playwrights. Historians of the English biography of the seventeenth century have perceived this as a lack. Stauffer (1964) complains that "[i]n the [prefatory] biographies of figures considered solely as artists, a period of sixty years yawns between Speght's Chaucerin 1598 and Davies' Hall (1656) or Sprat's Cowley (1668)" (266). Altick (1966) links the lack of writers' biographies with a general scarcity of biographical writing in England in that period on the one hand, and, on the other, attributes it to Renaissance ideas about the poet "as a mouthpiece, not an originator," which led to an "indifferen[ce] to men of letters as subjects of life narratives," which, in turn, prevented the creation of "well-filled biographical time capsules about [writers] for the instruction of future centuries." (12-13) Though Pritchard shows in a more recent critical survey of the English Biography in the Seventeenth Century (2005) that the "achievements in this area were much greater than one would suspect from the slight attention given to the seventeenth century in standard histories of English literary biography" (128), he still agrees that there is a scarcity of prefatory lives of writers, and in his discussion of prefatory lives published in the second half of the seventeenth century finds some of them wanting in depth and detail. 
However, this focus on "well-filled biographical time capsules" and detailed chronological prose narratives of writers considered "solely as artists," informed by a conception of literary biography that was developed only later in the eighteenth century, has long prevented critics from taking into consideration the multiple perspectives on authors' lives offered by other parts of the paratext. The edited volumes The Rhetorics of Life-Writing in Early Modern Europe (1995) and Writing Lives: Biography and Textuality, Identity and Representation in Early Modern England (2008) set out to change this situation. One of the aims of The Rhetorics of Life-Writing was to "challenge [...] formalist and generic distinctions, and to show the great variety of ways in which not simply prose biographers or historians, but also painters, poets, dramatists, preachers, and martyrologists took lives, individual and collective, as their concern." (Mayer and Woolf, 8) In their introduction to Writing Lives, Sharpe and Zwicker argue "that the conception of life writing as biography - the organic and developmental narrative of a life - imposes an anachronistic and circumscribed model on the writing of early modern lives" (3-4). ${ }^{2}$ They draw our attention to the fact that "prefaces, paratexts, dedications, and epistles" served as important "sites of early modern life writing" (7). The case studies collected in Writing Lives grasp "the fragmentary and episodic" as crucial for understanding early modern lives and early modern life writing (25).

The present essay aims to continue the projects of The Rhetorics of Life-Writing and Writing Lives and proposes to read the paratext of seventeenth-century books as a form of multi-generic, multi-perspective, and multi-modal form of life writing, since information on the life of an author is not only found in paratextually marked "(Accounts of) The Life of the Author." The time between Speght's life of Chaucer and the scattered prefatory lives of writers of the second half of the seventeenth century coincided with the proliferation of paratextual features such as engraved frontispieces, letters to the reader, notices from the stationer and, above all, commendatory poetry: verses in which the author and his or her work are recommended to prospective readers by other poets, acquaintances or family members (Williams, 1-5). Paratextual life writing is multi-generic because information about an author's life is not only presented in the form of prose narratives, but also in poems and, elliptically, on the title page. It is multi-perspective because various contributors collaborate to present the author's life and work from different angles. It is multi-modal because verbal information about the author is often complemented by visual representations of the author in the form of engraved frontispieces. "Life writing" is here not understood as "self-life writing," as defined by Smith and Watson (2010) in order to distinguish it from biographical writing (5-9), but in the broader sense outlined by 
Jolly (2001) as "encompassing the writing of one's own or another's life" and contributions from other art forms (ix). The term "life writing" is preferred over "biography" in the context of paratexts, since the latter term is closely linked to the idea of an "organic and developmental narrative of a life" (Sharpe and Zwicker, 3-4). The paratext of seventeenthcentury collections of poems and plays does not offer such a narrative, though it definitely offers writing about someone' else's life in the form of glimpses on an author's life, character and works. Drawing on Roland Barthes, these glimpses can be usefully grasped as "biographemes:" as "a few details, a few preferences, a few inflections" of the subject's life (9).

The life writing that took place in seventeenth-century paratexts is thus closer to conceptions of postmodern biography which emphasise multiple perspectives, discontinuous and non-chronological narrative structures, or fragmentariness (Nalepka, 393-4) than to conceptions of biography as "the organic and developmental narrative of a life." To a certain extent, thus, the life writing that takes place in seventeenth-century paratexts anticipates the insight of postmodern critics of life writing that biographies are always necessarily only fragmentary approximations to a subject (Heinrich, 368). In the following, this fragmentariness shall not be viewed as a deficiency but, instead, as a quality of openness, another feature proposed in discussions of postmodern biography (see Heinrich) and identified by Sharpe and Zwicker as part of a generic uncertainty present throughout the seventeenth century (8). What emerges from the reading of the paratext is not necessarily a unified image of the subject, but an array of aspects and possibilities, which cannot always be reconciled.

Fragmentary, multi-modal and pluralistic conceptions of the subject are thus not only found in innovative twenty-first century life writing practices. In fact, the paratext of seventeenth-century collections of poetry and plays bears a certain resemblance to virtual, twenty-first century presentations of authors on their websites, where, usually, different critics' voices (in the form of extracts from reviews), short biographical narratives, information about publications or pictures of the author are united. The functions of websites and seventeenth-century paratexts are similar, too: to attract prospective readers by praising the author's work and to offer information about the person behind the work. Both constitute attempts to make the lives and works of authors accessible from different angles and both offer the reader possibilities for interacting with the text. The reader, who is often directly addressed and thus encouraged to engage actively in a meaning-making process in the paratextual apparatus, can choose from, or try to synthesize, the various perspectives offered on the life and work of the author. As Sharpe and Zwicker 
remind us, "Renaissance rhetorical theory [which was still influential throughout the seventeenth century] fully recognized that the meaning of texts was as much made - as we have latterly recognized - by readers as by authors." (7)

"Thou liv'st to all that read" exclaims Fr. Finch in an apostrophe to the deceased author in one of the commendatory poems prefixed to Cartwright's works ("On Mr Will: Cartwright's excellent Poems," 1. 2). This apostrophe epitomises the central role of the reader in maintaining the author's memory. Though Finch refers to the reading of Cartwright's poems and plays, this statement just as much describes the (re-) construction of the author's life by the reader who encounters the paratext. This construction of the author by the reader, however, presupposes that the paratext was read in the first place. As Anderson, Patterson or Brayman Hackel have convincingly shown, the paratext of early modern books was indeed considered an integral part of the book. Anderson (2002) provides examples of authors who condemn their stationers for not including a certain preface, and further cites a Star Chamber decree forbidding the unauthorized publication of all front matter whatsoever (637-8); Patterson draws attention to the fact that the "Printing Act of 1662 required that all 'Titles, Epistles, Prefaces, Proems, Preambles, Introductions, Tables, Dedications,' be brought to the licenser for scrutiny along with the main body of the text" (56) and Brayman Hackel, in her study of reading in early modern England (2005), shows how paratexts "clearly arrested the attention of early modern audiences" (69; fn.1). ${ }^{3}$ Saenger (2006) agrees that "front matter was the central way for early modern readers to approach, engage with, and understand books" (1-2). After all, before the introduction of periodicals, the paratext of books provided one of the few, if not the only, site of discussing the contents of a book. Addresses to the reader, also, were not necessarily only rhetorical: readers were sometimes asked by editors to contribute poems of deceased authors to new editions or were thanked by authors or publishers in their prefaces for their help in compiling the volume at hand. ${ }^{4}$

\section{THE PARATEXT OF WILLIAM CARTWRIGHT'S COMEDIES, TRAGI-COMEDIES, WITH OTHER POEMS}

In the following, I shall read the paratext of William Cartwright's Comedies, Tragi-Comedies, With other Poems (1651) as an example of seventeenthcentury life writing, examining where and in what form biographemes are presented to the reader and how they contribute to the creation of certain images of Cartwright. The paratext consists of an engraving of 
the author's image on the frontispiece, the title page, a dedication of the stationer to the University of Oxford, an epistle "To the reader" written by Humphrey Moseley (seven pages), fifty-five commendatory poems (107 pages), a poem from "The Stationer" to the reader, a Postscript and a list of errata. Separate title pages introduce Cartwright's plays (The Lady Errant, The Royall Slave, The Ordinary, The Siedge: Or, Love's Convert) and his "Poems". ${ }^{5}$

The first impression of the author is created by the portrait on the frontispiece (see Figure 1). According to Ezell (2012), "the desire for engraved frontispieces and author portraits significantly increased after the 1640s" (34), ${ }^{6}$ a development which, I would argue, goes hand in hand with the increasing amount of biographical information provided on an author in the paratext in general. The portrait of Cartwright is signed "Lombart, sculp." and was not made by one of the usual collaborators of Humphrey Moseley, the publisher of Cartwright's work. Since the portrait bears the date 1643 it was probably not originally commissioned for the inclusion in Cartwright's published works, but only used for this purpose later by the publisher. Moseley generally "attached importance to the inclusion of the author's engraved likeness at the front of the book" (Kewes 1995, 7). A quick survey of about twenty frontispieces of books including author portraits published by Moseley between 1646 and 1656 shows that Cartwright's portrait is exceptional in that it is the only one showing the author in a reclining rather than an upright position and in that it lacks highly stylized, emblematic attributes, such as the laurel wreath, which feature prominently in many of the other prefatory portraits. Also, the author's portrait is not framed by a stylized oval or rectangular picture frame; instead, the author, pictured sitting on a writing desk on which an opened volume of Aristotle's works is displayed, is framed by book shelves on the top of the picture ${ }^{7}$ and an eight-line poem addressed to the poet himself at the bottom. The portrait of the author is not modelled on classical busts, but rather seems to aim at a verisimilar depiction of Cartwright. The work setting, the casual pose and the melancholic expression on the young man's face together with the fact that he seems to be looking not into the distance, but, rather questioningly, at the prospective reader, creates an atmosphere of intimacy which is rarely achieved by other portraits prefixed to books in mid-seventeenth century England. Cartwright is, from the very beginning, presented as an individual and not as a run-of-the mill writer who is reduced to schematic and exchangeable features. The reader thus gets a visual impression of the man before any biographemes are provided in the form of verbal statements; Cartwright is presented as a man of letters, a scholar who reads Greek (the Greek letters in the opened book are visible and the 


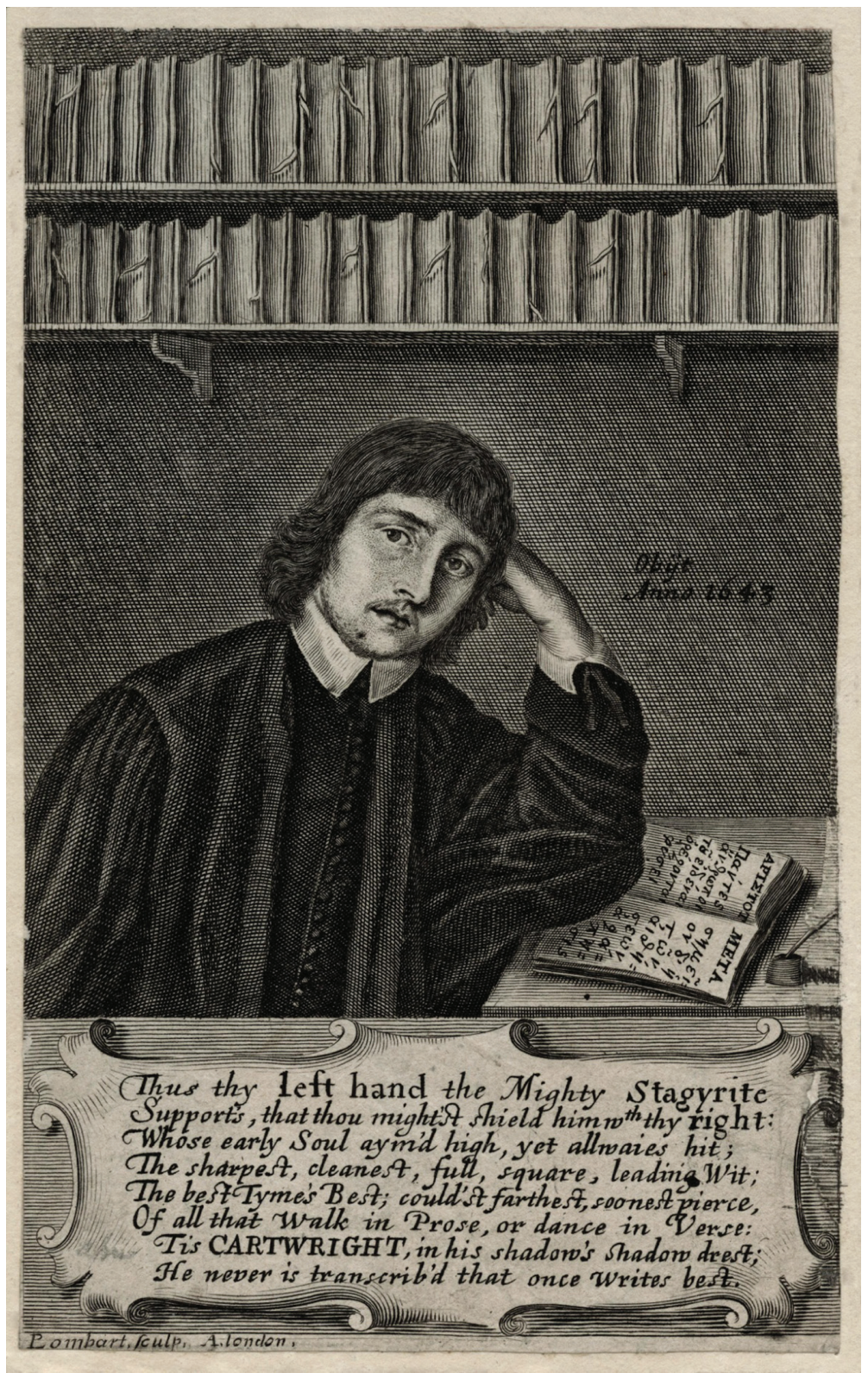

Figure 1: Engraved Portrait of William Cartwright included in the frontispiece of Comedies, Tragi-Comedies, With other Poems (1651).

(@) National Portrait Gallery, London) 
"Stagyrite," Aristotle, is identified as its author in the lines accompanying the portrait). Cartwright's name is then given, in capital letters, in the penultimate line of the poem at the bottom of the frontispiece.

Humphrey Moseley seems to have been aware of the unusualness of this portrait, since he found reason to explain it in his epistle to the reader. In the course of the explanation he does not only introduce the readers to Cartwright's daily habits, but provides some information on the author's education: "Some perhaps may quarrell with the Frontispeece ( a man in a Gown before a Book of Poems: ) Such may know 'twas done on purpose: we could have dress'd him with Chaplets and Laurel, Cloak'd, and Embroyder'd, as well as others: but, since he first went to the King's Schoole at Westminster till he went out of the World, he was ever in a Gown: [...]." Though Cartwright's dress, being that of a scholar, might not present an unusual choice as such, together with the lack of the symbolic laurel wreath and the overall composition of the portrait it marks a departure from the conventional style of mid-seventeenth century frontispieces, especially those published by Moseley. Thus instead of presenting Cartwright along conventional models, Moseley and whoever else might have been involved in the posthumous publication of Cartwright's works, made the conscious decision to present the author to a certain extent as individualised in the paratext. They documented and pointed out idiosyncrasies of the individual author they deemed worth remembering.

But before the audience would have encountered Moseley's epistle to the reader, it would have seen the title page of Cartwright's works. With its descriptive and generic title, Comedies, Tragi-Comedies, With other Poems, this title page does not only introduce the author as playwright and poet and provide a kind of reduced table of contents of the works to follow, but also offers elliptical signposts to two further aspects of Cartwright's life which will then be to some extent elaborated in the remaining parts of the paratext: Cartwright the scholar and Cartwright the Royalist.

While the author was presented in a very life-like fashion in the portrait on the frontispiece, the seventh line of the title page confronts the reader with the fact that William Cartwright is already dead, since he is introduced as the "late Student of Christ-Church in Oxford." At the same time, information about his alma mater and thus his educational background is provided, which implies that he was either from a wealthy family background or lucky enough to have gained access to the university on the basis of a scholarship, which would have made him part of an elite. That Cartwright was a successful student becomes clear from the next line: not only was he a student at Oxford, but also a "Proctor of the University," a university official. His presentation as scholar, begun by the portrait which shows Cartwright surrounded by books and a quill, is thus 
continued here and is further elaborated in the epistle to the reader and the commendatory poems to follow. On the title page, it is also supported by the inclusion of an elliptical quotation from the epilogue of Ovid's Metamorphoses: "nec Ignes, / Nec potuit Ferrum." These lines further present a bold statement about the durability of Cartwright's work by way of the implied comparison with Ovid's great poem. Humphrey Moseley's dedication to the University on the following page supports Cartwright's affiliation with the University of Oxford.

Still on the title page, the reader is told that Cartwright's songs were set to music by Henry Lawes, a composer associated with king Charles I, which, on the one hand, points to Cartwright's success and artistic achievement and, on the other, sketches his political background, which would have been of interest to an English reader buying a book in 1651: two years after the execution of Charles I and two years into the Commonwealth established by Oliver Cromwell, Cartwright is firmly identified as a Royalist writer. Cartwright's political affinities are reinforced by the information that the book was printed for Humphrey Moseley, who published the work of many Royalist poets in mid-seventeenth century England. As Kewes (1995) has shown, in the epistle to the reader Moseley makes his own Royalist affiliation and the audience he had in mind (namely "the former Cavaliers and their families, by now seriously impoverished"; 11) explicit by promoting the affordability of the volume, explaining that "we see it is such weather that the most ingenious have least money." Cartwright's Royalist background is supported by some of the commendatory poems, not only by such anecdotes as the one included by Henry Vaughan, who exclaims "Thou art the Man, whom great Charles so exprest!" in "Upon the Poems and Plaies of the ever Memorable Mr. Will. Cartwright" (1. 40), but also by the identities of some of the commendatory poets who were known for their staunch Royalism, such as John Berkenhead.

The epistle "To the Reader" provides some fragments of the author's life and an incomplete list of his works in the form of a short prose narrative. The information that the author is dead is repeated right at the beginning, and it is this circumstance that provides the justification for including any information on Cartwright at all in the epistle: "The Book in your hand, were the Author living, should say nothing to the Reader: And here we but tell you, how we have us'd Him in publishing his Poems," similar openings are used in other biographical paratexts in the seventeenth century. ${ }^{9}$ Despite the initial claim that the epistle will "but tell [the reader] how we have us'd Him in publishing his Poems," Moseley provides information on Cartwright's education, his career as scholar and divine, his death and his age at the time of his death, and, as we have seen above, some of his personal preferences, such as his clothing habits and his style of lecturing. He does 
not, however, provide any details on Cartwright's ancestry and family. That he was not from a noble background can, however, be deduced from the fact that no title of nobility is included on the title page.

Moseley explains how the works now collected under Cartwright's name had to be saved from plagiarists who published some of the author's plays and poems under their own names since his death. In the context of this explanation, Moseley forges a strong link between Cartwright and his work, and places an emphasis on the importance of Cartwright being the sole originator of all the works the reader is about to encounter; so the identity and person of the author is, after all, presented as having an impact on the reception of the work that is being introduced.

The information on Cartwright's education and clothing habits is given before readers are told that Cartwright was a "Master in Poetry," a "Scholar" and a "great Orator." A short excursion concerning poets in antiquity follows, before the authority of Ben Jonson is invoked to support Moseley's praise of Cartwright's qualities: "There are can witness, that our ablest Judge E Professor of Poesie, said with some passion, My Son Cartwright writes all like a Man: You'l soon guess 'twas Ben Iohnson spake it: [...]." On the penultimate page of the epistle the reader is told that Cartwright was also a "divine," a churchman, and it is emphasized that he composed most of the poems before he entered Holy Orders (probably in order to forestall any criticism a churchman writing poetry might have to face) and before he turned twenty, and it is presented as remarkable that a young man was able of such feats, a staple topos of praise familiar from commendatory verse. In the same breath, the range of Cartwright's output is praised: "If the Witts read his Poems, Divines his Sermons, Philosophers his Lectures on Aristotle's Metaphysicks, they will scarce beleeve He dyed at thirty." This reference to the variety of Cartwright's work shows how inappropriate Stauffer's complaint about the lack of prefatory lives depicting the author only as artist actually is: such a life would not have mirrored the reality of seventeenth-century writing, since one was not usually "only" an author of literary texts then. ${ }^{10}$ On the final page of the letter the reader learns the names of Cartwright's patrons and supporters before his cause of death - "a fatall choice Feaver" - is given.

The biographemes provided by Moseley in the epistle to the reader are supplemented by a total of fifty-five commendatory poems, ranging in length from fourteen lines to seven pages. The quality of the poems varies and the commendatory poets adopt different approaches, which results in a series of distinct voices contributing to the collaborative presentation and recommendation of Cartwright. Commendatory verse is heavily marked by generic conventions, and many of the features employed in the paratextual apparatus are not particular to the presentation of Cartwright: there 
is usually no mediocrity in the judgment and description of the poet, the poet is glorified and praised, often with the help of hyperbolic language, metaphors and similes, the poet is presented as manly, and compared favourably with writers of antiquity (Biester 1993, 507).

However, I agree with Chandler $(2003,129)$ that commendatory verses provide more room for potential individualisation of the author than has been assumed, by, amongst others, Williams (1966). In the case of the poems introducing Cartwright's work, the individualising impulse begun on the title page and continued by Moseley in the epistle to the reader can also be traced in some of the commendatory poems. In the first place, however, the sheer number - fifty-five poems - testifies to the popularity of the poet and his work and is a means of singling out the writer from his contemporaries, since usually no more than five to ten poems were prefixed to an author's work. Moseley justifies the abundance of commendatory verse and connects the justification with further praise of Cartwright's character traits: "if you think He hath too many Commenders, it is a sign you knew him not: we grant here are more than before other Books, and yet we give you not all we have. The truth is, His high abilities were accompanied with so much Candour and Sweetness that they made him equally lov'd and admir'd: for it is a debt to vertuous Modesty, that those receive most Honour who least seek it."

Not only Moseley, who must have collected and commissioned the more than fifty poems, commented on this huge collaborative effort to present and praise Cartwright, first in his letter and then in his poem to the reader, which frame the commendatory bulk of the paratext. Many of the other poets also express an awareness of their joint effort to present the author to the public, and, in places, this acknowledgment goes hand in hand with reflections about the conventions of the prefatory paratext and with questions about how to present Cartwright adequately. Henry Vaughan, who confesses at the very beginning of his poem that he did not know Cartwright personally (he "did but see" him) but was familiar with his works, expresses his qualms about adding any material to the paratext of Cartwright's work and at the same time comments on the conventions of introducing authors in the context of their published works:

\footnotetext{
I fear to sin thus near thee; for (great Saint!)

'Tis known, true beauty hath no need of paint.

Yet, since a Labell fixt to thy fair Hearse

Is all the mode, and Tears put into Verse

Can teach Posterity our present grief,

And their own loss, but never give relief;

I'll tell them (and a truth which needs no Pass)

That Wit in Cartwright at her Zenith was. ("Upon the Poems and Plaies of the ever Memorable Mr Will. Cartwright," 11. 5-12)
} 
Io. Fell wonders how the surviving poets, if they are not even up to praising Cartwright properly as a poet should go about praising him as a person: "[...] how shall we than / That cannot speak the Poet, praise the Man?" ("On Mr William Cartwright's excellent Poems, collected and published since his Death," 11. 37-38) By asking this question, he employs the "inexpressibility topos" (Scodel 1991, 130) which, along with "outdoing (subject surpasses all those with whom he is compared), and universal renown [...] which is claimed for the dead man and his acts" has been identified as a central topic of Renaissance funeral elegies indebted to conventions of "classical and medieval praises" (Bloomfield 1986, 152). The poems prefixed to Cartwright's works draw on these traditions and on that of the critical elegy, which was "particularly prevalent in the earlier half of the seventeenth century" (Lyon 2003, 267). The models for such critical elegies, which combine the functions of commendatory poetry with expressions of lament, were established by poems written both by and for Ben Jonson, centrally expressing the idea that "the works [of a poet are] a more enduring monument than any tomb" and declaring a poet's "poetic immortality" (Lyon, 270).

In his own attempt to praise Cartwright, Fell focuses on Cartwright's didactic skills as lecturer and his compelling way of preaching sermons:

\footnotetext{
Paint in what figure, colour, or design,

The deep Philosopher or grave Divine?

Express him when he held us forth his light,

Unridling to us the dark Stagyrite? [...]

Or view him when his riper thoughts did bear

His studies into a Diviner Sphere:

When that his Voice did Charm th'attentive Throng,

And every Ear was link'd unto his Tongue,

The numerous preass, closing their souls in one,

Stood all transform'd into his Passion. (11. 39-42; 47-52)
}

The same skills are praised in many of the other poems, which would suffice to create a lasting image of Cartwright the able lecturer and preacher simply by way of repetition, but especially the effect he had on his audience is emphasized with the help of hyperbolic metaphors, as in the following passage taken from Berkenhead's poem:

Then, then what dreadfull Sweetnesse didst thou show,

Making the Learned admire, and tremble too!

Thunder was set in tunes; the Temple shak'd,

Graves of each Bosome open'd, Dead sins wak'd,

Lightning, and Darknesse, Earthquakes, every thing

As if the Jewes re-crucifi'd their King. (11. 148-52) 
W. Towers remembers Cartwright as follows: "How did'st thou Pray! how Preach! how didst thou move / Thy Hands and Eyes! they and the Word our Love!" (W. Towers, “On Mr William Cartwright's surviving Poems", 11. 123-24), which makes Cartwright almost come alive for the reader, not just because of the intensity of the expression, but also because of the speaker's personal involvement ("the Word our Love").

The juxtaposition of hyperbolic praise and personal memories of the author, a strategy found in many of the poems, constitutes a possible answer to Fell's question as to how one can write adequately about the deceased author. Sometimes, the mythical takes the place of factual life writing: While no information about Cartwright's family background is provided anywhere in the paratext, he is equipped with a literary pedigree:

He may be Johnson's Grand-Child, Fletchers Son.

If by desert, a Muse might be his Mother,

He Homer's Heir, and Hesiod's elder Brother.

Nature allow'd, when she did Cartwright mould,

Not one and Thirty years to make him old. (Robert Stapylton K., "On Mr Cartwright and his Poems", 11. 26-30)

As Enenkel (2013) has shown, the construction of spiritual fatherhood is a strategy often found in the lives of artists and scientists (28). Here, this strategy of providing a literary heritage for Cartwright, which inscribes him firmly into a literary tradition on the hand and results in a presentation of Cartwright as mythical poet-hero on the other, is directly combined with the worldly information about the actual age at which he died.

In Smallwood's poem, the dead man's presence is evoked by lines such as "See! He looks pale and pensive still! but This / The Scholars Grace, and chiefest Beauty is;" ("On the Death of Mr Cartwright, and the Life of his desired Poems," 11. 27-8) after he has been presented at the beginning of the same poem as a mythical superhuman, "who alive could quell / All Hydra, and subdue each Limb of Hell” (11. 7-8). Cartwright's looks are rudimentarily referred to here and mentioned again later in the same poem, when Smallwoord addresses the reader and describes Cartwright's looks, which resemble those pictured on the frontispiece: "do not blame his serious Brow and Look" (1. 37). In W. Waring's poem Cartwright is first called "The Author and the Subject of all Verse" ("On his Deceased Friend Mr Will: CARTWRIGHT's Poems, now Collected and Published," 1. 8), before some features of his character are illustrated by his habits: "He broke no Midnight-Sleep / To be, of be thought, deep; / His Oyle for others spent; / On Publick Errands sent; / He out-read most, but out-writ more, and yet / Did alwaies teach more than he read or writ." (11. 27-32) Stapylton muses about the attractions of the poet's person and his poetry: 


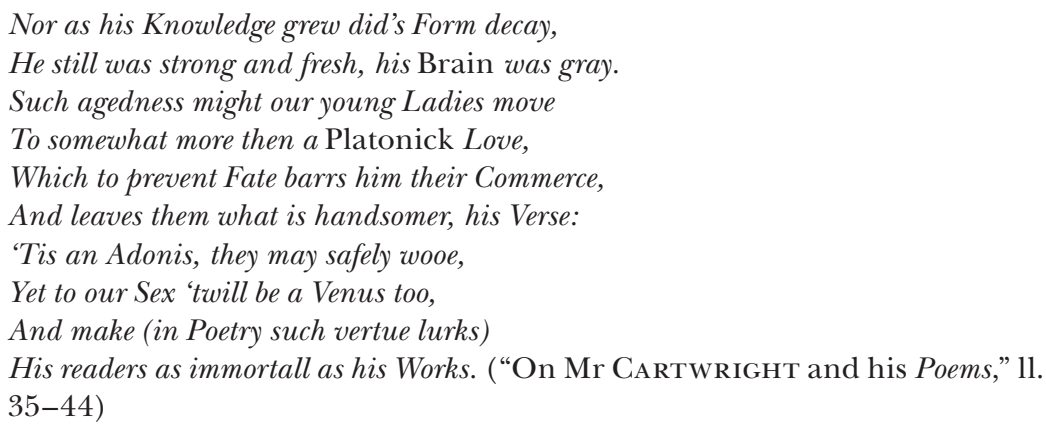

The picture Stapylton paints of Cartwright clashes to some extent with the characterizations of the man offered by Howe and Berkenhead: "...no man durst loosely come nigh/A lip, while his chast tooth was by;" says Howe ("On MrWilliam Cartwright's excellent Poems",1l.39-40), whileBerkenhead stresses that Cartwright's dramatic works were certainly not the result of alcoholic intake:

\section{[...] Thou didst not write}

Warm'd by male Claret or by female White:

Their Giant Sack could nothing heighten Thee,

As far 'bove Tavern Flash as Ribauldry. ("In Memory of Mr William CartWRIGHT," 1l. 131-4)

He presents Cartwright as a morally upright man who did not indulge in worldly pleasures before he goes on to discuss the qualities of Cartwright's dramatic works:

No rotten Phansies in thy Scenes appear;

Nothing but what a Dying man might hear.

All of all Sexes may pronounce or show it,

Thou (as old Prophets) were anointed Poet: (11. 141-44)

Berkenhead thus links Cartwright's own morally sound life with the laudable qualities of his work and the suitability of his work for all audiences.

\section{CONCLUSION}

Indeed, throughout the paratext a close link is created between Cartwright as person and his work, be it with the help of assertions of Cartwright as the true originator of his work or by linking his presentation as mythical poet-hero with critical discussions of his writing style or the 
reception of his particular works. That such a close connection between authors and their work was perceived seems to have functioned as an underlying justification for including any information on Cartwright at all, even if it is combined with idealising and conventionalised panegyric writing. As Jessica Martin has shown, life writing in the seventeenth century was generally heavily informed by existing models and conventions, such as exemplary lives of saints, the Greek encomium, or the funeral sermon, features of which are also found in commendatory verse. In the paratext of William Cartwright's Comedies, Tragi-Comedies, With otherPoems, standard elements of the paratext combined with biographemes provided by the various contributors create a multi-faceted, though open image of Cartwright's life and work. If we read the paratext of seventeenth-century books with the help of features outlined for postmodern life writing rather than with the help of Enlightenment from-the-cradle-to-the-grave models of biography, we can expand the corpus of early modern life writing of authors and it allows us to see such forms not as defective, but as varieties of life writing in their own right.

\section{WORKS CITED}

Altick, Richard D. Lives and Letters: A History of Literary Biography in England and America. 2nd ed. New York: Knopf, 1966. Print.

Ammon, Frieder v., and Herfried Vögel. "Einleitung." Die Pluralisierung des Paratextes in der Frühen Neuzeit: Theorie, Formen, Funktionen. Ed. Frieder v. Ammon. Berlin u.a: Lit, 2008. vii-xix. Print. Pluralisierung \& Autorität 15.

Anderson, Randall. "The Rhetoric of Paratext in Early Printed Books." The Cambridge History of the Book in Britain. Ed. John Barnard and D. F. McKenzie. Cambridge: Cambridge Univ. Press, 2002. 636-44. Print. IV 1557-1695.

Barthes, Roland. Sade, Fourier, Loyola. London: Jonathan Cape, 1977. Print.

Benton, Michael. Literary Biography: A Introduction. Malden, Mass: Wiley-Blackwell, 2009. Print.

Berensmeyer, Ingo. "Angles of Contingency": Literarische Kultur im England des siebzehnten Jahrhunderts. Tübingen: Niemeyer, 2007. Print.

Biester, James. "Gender and Style in Seventeenth-Century Commendatory Verse." Studies in English Literature, 1500-1900 33.3 (1993): 507-22. Print.

Bloomfield, Morton W. "The Elegy and the Elegiac Mode: Praise and Alienation." Renaissance Genres: Essays on Theory, History, and Interpretation. Ed. Barbara K. Lewalski. Cambridge, Mass. and London: Harvard University Press, 1986. 147-57. Print. Harvard English studies 14.

Bold, Henry, and William Bold. Latine Songs with their English, and Poems. London: Printed for John Eglesfield, 1685. Print.

Brayman Hackel, Heidi. Reading Material in Early Modern England: Print, Gender, and Literacy. Cambridge, U.K, New York: Cambridge University Press, 2005. Print.

Cartwright, William. Comedies, Tragi-comedies, With Other Poems. London: Printed for Humphrey Mosely, 1651. Print.

Chandler, Wayne A. Commendatory Verse and Authorship in the English Renaissance. Lewiston, NY: Edwin Mellen, 2003. Print. Mellen studies in literature Elizabethan and Renaissance studies 129. 
Chaucer, Geoffrey, Thomas Speght, and John Lydgate. The Workes of our Antient and Learned English Poet Geffrey Chavcer [i.e. Geoffrey Chaucer]: Newly printed ... London, At the charges of Thomas Wight: Printed by Adam Islip, 1598. Print.

Danton, J. P. "William Cartwright and His "Comedies, Tragi-Comedies, with Other Poems..." 1651.” The Library Quarterly 12.3 (1942): 438-56. Print.

Du Fresnoy, Charles A., John Dryden, and Richard Graham. De arte graphica: The art of painting. London: Printed for J. Heptinstall for W. Rogers, 1695. Print.

Enenkel, K. A. E. "Vita als Instrument humanistischer Wissensvermittlung: Desiderius Erasmus, Beatur Rhenanus, Guillaume Budé, Louis Le Roy und Johannes Sturm." Die "Vita" als Vermittlerin von Wissenschaft und Werk: Form- und funktionsanalytische Untersuchungen zu frühneuzeitlichen Biographien von Gelehrten, Wissenschaftlern, Schriftstellern und Künstlern. Ed. K. A. E. Enenkel. Berlin: Lit, 2013. 11-81. Print. Scientia Universalis: Abteilung I, Studien zur Wissenschaftsgeschichte der Vormoderne 1.

Ezell, Margaret. "Seventeenth-Century Female Author Portraits, Or, The Company She Keeps." ZAA 60.1 (2012): 31-46. Print.

Genette, Gérard. Paratexts: Thresholds of Interpretation. Cambridge, New York, NY, USA: Cambridge University Press, 1997. Print. Literature, culture, theory 20.

Heinrich, Tobias. "Die montierte Biographie: Alexander Kluges Lebensläufe als Modell 'offener' Biographik." Die Biographie - Beiträge zu ihrer Geschichte. Ed. Wilhelm Hemecker. 1st ed. Berlin: De Gruyter, 2009. 367-92. Print.

Hierocles, and John Hall. Hierocles upon the golden verses of Pythagoras. London: Printed by John Streater for Francis Eaglesfield at the signe of the Marigold in Saint Pauls Churchyard, 1657. [i.e. 1656. Print.

Jardine, Lisa. Erasmus, Man of Letters: The Construction of Charisma in Print. Princeton, NJ: Princeton University Press, 1993. Print.

Jolly, Margaretta. "Editor's Note." Encyclopedia of Life writing: Autobiographical and Biographical Forms. Ed. Margaretta Jolly. 2 vols. London and Chicago: Fitzroy Dearborn, 2001. ix-xii. Print.

Kastan, Davis S. "Humphrey Moseley and the Invention of English Literature." Agent of Change: Print Culture Studies after Elizabeth L. Eisenstein. Ed. Sabrina A. Baron, Eric N. Lindquist, and Eleanor F. Shevlin. Amherst, Washington, D.C: University of Massachusetts Press; In Association with the Center for the Book, Library of Congress, 2007. 105-24. Print. Studies in print culture and the history of the book.

Kewes, Paulina. "'Give Me the Sociable Pocket-Books...': Humphrey Moseley's Serial Publication of Octavo Play Collections." Publishing History 38 (1995): 5-21. Print.

Lyon, John. "The Critical Elegy." A Companion to English Renaissance Literature and Culture. Ed. Michael Hattaway. Oxford: Blackwell, 2003. 267-75. Print.

Machan, Tim W. "Speght's "Works" and the Invention of Chaucer." Text 8 (1995): 145-70. Print.

Marotti, Arthur F. Manuscript, Print, and the English Renaissance Lyric. Ithaca and London: Cornell Univ. Press, 1995. Print.

Martin, Jessica. Walton's Lives: Conformist Commemorations and the Rise of Biography. Oxford [England], New York: Oxford University Press, 2001. Print.

Mascuch, Michael. "Britain: Renaissance Life Writing." Encyclopedia of Life Writing: Autobiographical and biographical forms. Ed. Margaretta Jolly. 2 vols. London and Chicago: Fitzroy Dearborn, 2001. 132-34. Print.

Mayer, Thomas F., and D. R. Woolf. "Introduction." The Rhetorics of Life-writing in Early Modern Europe: Forms of Biography from Cassandra Fedele to Louis XIV. Ed. Thomas F. Mayer and D. R. Woolf. Ann Arbor: University of Michigan Press, 1995. 1-37. Print. Studies in medieval and early modern civilization.

Nalepka, Cornelia. "Postmoderne Biographik: Dieter Kühns $N$ und Hans Magnus Enzensbergers Der kurze Sommer der Anarchie.” Die Biographie - Beiträge zu ihrer Geschichte. Ed. Wilhelm Hemecker. 1st ed. Berlin: De Gruyter, 2009. 393-421. Print. 
Patterson, Annabel M. Censorship and Interpretation: The Conditions of Writing and Reading in Early Modern England; with a New Introduction. [repr.]. Madison, Wis. and London: Univ. of Wisconsin Press, 1984. Print.

Perry, Kathryn. "'I do it onely for the Printers sake:”: Commercial Imperatives and Epigrams in the Early Seventeenth Century." EnterText 3.1 (2011): 204-26. Print.

Pritchard, Allan. English Biography in the Seventeenth Century: A Critical Survey. Toronto u.a: Univ. of Toronto Press, 2005. Print.

Saenger, Michael. The Commodification of Textual Engagements in the English Renaissance. Aldershot, England, Burlington, VT: Ashgate Pub., 2006. Print.

Scodel, Joshua. The English Poetic Epitaph: Commemoration and Conflict from Jonson to Wordsworth. Ithaca, N.Y: Cornell University Press, 1991. Print.

Sharpe, Kevin, and Steven N. Zwicker. "Introducing Lives." Writing Lives: Biography and Textuality, Identity and Representation in Early Modern England. Ed. Kevin Sharpe and Steven N. Zwicker. Oxford: Oxford University Press, 2008. 1-26. Print.

Snider, Alvin. "Britain: 17th-Century Life Writing." Encyclopedia of Life Writing: Autobiographical and biographical forms. Ed. Margaretta Jolly. 2 vols. London and Chicago: Fitzroy Dearborn, 2001. 134-36. Print.

Smith, Sidonie, and Julia Watson. Reading Autobiography: Interpreting Life Narratives: University of Minnesota Press, 2010. Print.

Stauffer, Donald A. English Biography Before 1700. Reissued. New York: Russell Russell, 1964. Print.

Voss, Paul J. "Books for sale: Advertising and Patronage in Late Elizabethan England." The Sixteenth Century Journal: The Journal of Early Modern Studies 29 (1998): 733-56. Print.

Wendorf, Richard. The Elements of Life: Biography and Portrait-Painting in Stuart and Georgian England. Oxford: Clarendon Press, 1991. Print.

Williams, Franklin B., Jr. "Commendatory Verses: The Rise of the Art of Puffing." Studies in Bibliography 19 (1966): 1-14. Print.

\section{ABOUT THE AUTHOR}

Sarah Herbe (sarah.herbe@sbg.ac.at) is assistant professor at the Department of English and American Studies, University of Salzburg. In the framework of her habilitation project she examines paratextual life writing found in 17th and 18 th-century poetry collections. Recent publications include a journal article on Thomas Beedome (2014), the monograph Characters in New British Hard Science Fiction (Winter, 2012), and the edited volume Life Course Models in Literary Genres (Winter, 2011). Forthcoming publications include one book chapter on Dryden's prefatory essays and one on life writing projects in posthuman science fiction. In 2011, she won the "Award for Excellent Teaching" of the University of Salzburg for a seminar on "Women's Life Writing."

\section{NOTES}

1 Genette (1997) distinguishes between "peritext" and "epitext"; peritext referring to everything that is included within the book apart from the "text proper" (p. 5). However, since, as for example Ammon and Vögel (2008) have pointed out, the distinction does not really 
make sense before the eighteenth century (p. xii); I shall use the term "paratext" to refer to the front matter of books in this essay.

2 See also Mascuch (2001) and Snider (2001) on this point.

3 On the role of the early modern reader, see also Marotti (1995) pp. 135-7 or Perry (2011) pp. 211-12.

4 See for example Henry Bold's Latine Songs, with their English: And Poems (1685), or Dryden's preface to his translation of "De Arte Graphica" (1695).

5 As Danton (1942) has painstakingly shown in his essay on the "bibliographical questions and peculiarities concerning the collected edition of [Cartwright's] plays and poems" (p. 438), there are "numerous variations and differences in individual copies" of Cartwright's works (pp. 443-4). This analysis is based on the copy in the British Library, accessed via the Early English Books Online database.

6 See also Wendorf (1991), p. 12, fn. 38.

7 See Jardine (1993) pp. 76-79 on the function of books in portraits of authors.

8 The full passage reads, in translation, "Now stands my task accomplished, such a work/As not the wrath of Jove, nor fire nor sword / Nor the devouring ages can destroy."

9 See for example the beginning of John Davies' "An Account of the Author of this Translation, and his Works", prefixed to John Hall's Hierocles upon the golden verses of Pythagoras (1656): "Since it hath pleased that irresistible Destiny, which disposes of all things, to snatch hence the great Author of this work, while the Presse was in labour with it, it is thought fit the world should not be depriv'd of the satisfaction it might receive by some account of him, both as to this \& his other Writings."

10 See, for example, Berensmeyer (2007) p. 23. 